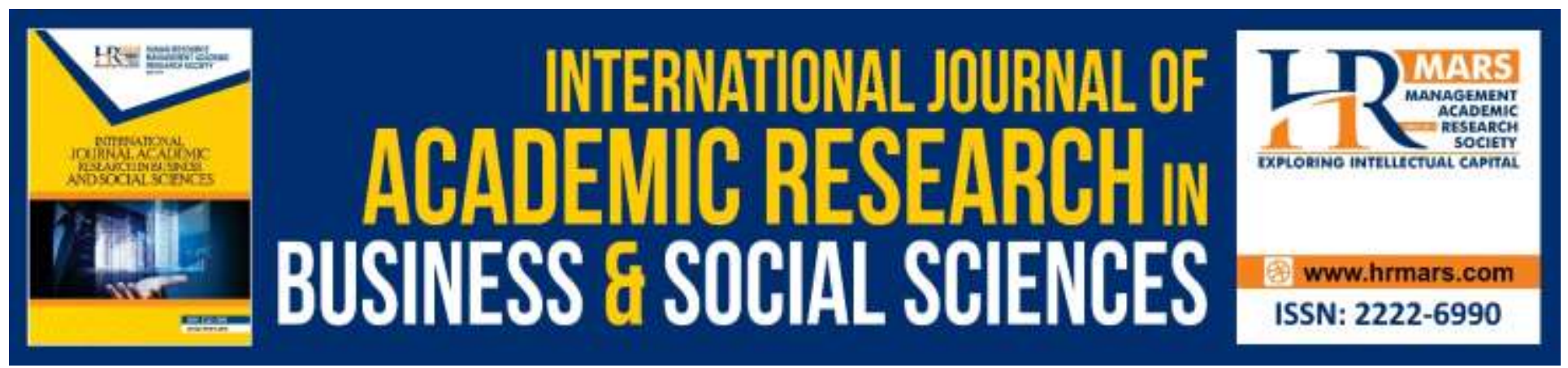

\title{
Perceptions and Expectancies of Malaysian Students on Cultural Elements in Foreign Textbooks
}

Precintha Rubini James, Azlina Abdul Aziz

To Link this Article: http://dx.doi.org/10.6007/IJARBSS/v10-i4/7122

DOI:10.6007/IJARBSS/v10-i4/7122

Received: 02 February 2020, Revised: 12 March 2020, Accepted: 24 March 2020

Published Online: 17 April 2020

In-Text Citation: (James \& Aziz, 2020)

To Cite this Article: James, P. R., \& Aziz, A. A. (2020). Perceptions and Expectancies of Malaysian Students on Cultural Elements in Foreign Textbooks. International Journal of Academic Research in Business and Social Sciences, 10(4), 214-231.

\section{Copyright: (C) 2020 The Author(s)}

Published by Human Resource Management Academic Research Society (www.hrmars.com)

This article is published under the Creative Commons Attribution (CC BY 4.0) license. Anyone may reproduce, distribute, translate and create derivative works of this article (for both commercial and non-commercial purposes), subject to full attribution to the original publication and authors. The full terms of this license may be seen at: $\underline{\text { http://creativecommons.org/licences/by/4.0/legalcode }}$

Vol. 10, No. 4, 2020, Pg. 214 - 231

Full Terms \& Conditions of access and use can be found at http://hrmars.com/index.php/pages/detail/publication-ethics 


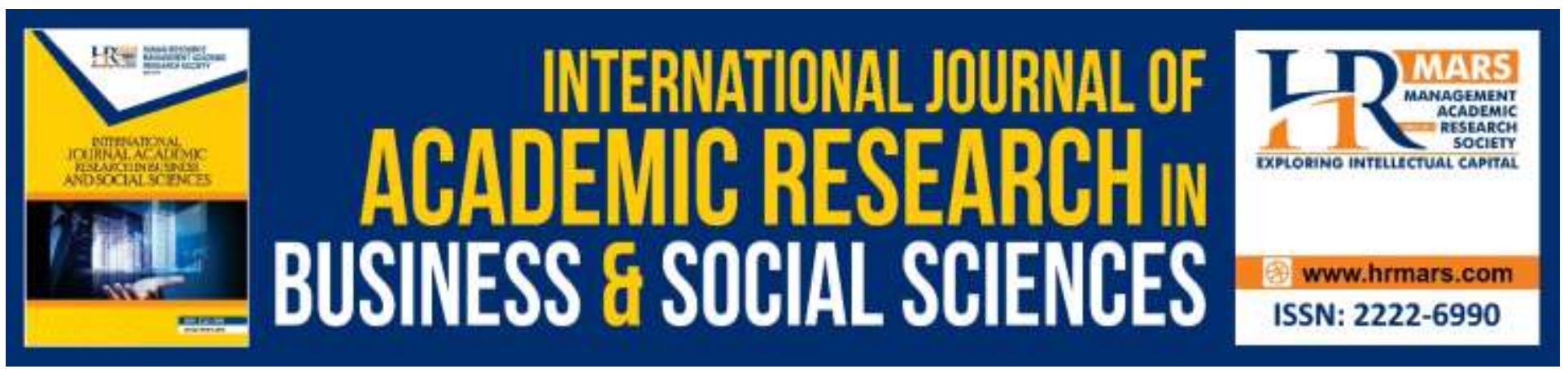

\title{
Perceptions and Expectancies of Malaysian Students on Cultural Elements in Foreign Textbooks
}

\author{
Precintha Rubini James \\ SMK Seri Bentong, Pahang; Universiti Kebangsaan Malaysia, Malaysia \\ Email: preciz16@yahoo.com \\ Azlina Abdul Aziz \\ Faculty of Education, Universiti Kebangsaan Malaysia, alaysia \\ Email: azlina1@ukm.edu.my
}

\begin{abstract}
The role of culture in foreign textbooks has received considerable attention in the past few years. Many argue on the cultural gap between the ESL learners in Malaysia and the usage of foreign textbooks in the teaching and learning of English Language. Thus, this quantitative study explored students' perceptions and expectancies on cultural elements in a Malaysian secondary foreign textbook entitled Pulse 2, to answer three research questions: (1) What are the students' perceptions on cultural elements in Pulse 2, (2) What are the students' expectancies on cultural elements that should be depicted in the textbook and (3) What are the students' perceptions on culture and cultural learning? A survey was conducted by distributing an adapted version of questionnaire from Xiao. The study found that the students perceive that there is a great absence of Source and International Culture in the book and there is a higher preference for little ' $c$ ' culture learning as it is the direct outcome of socio-cultural values and positively inclined towards culture learning. In conclusion, there are various aspects that need improvements in constructing textbooks, to produce good language users. Many pedagogical implications were discussed and trends for future research were suggested. Keywords: ESL, Foreign Textbooks, Cultural Elements, Categories of Culture, Types of Culture
\end{abstract}

\section{Introduction}

\section{Background of the Study}

The vital role of English Language and communicative necessity in the global market have led the people around the world to prioritise the mastery of the language in almost every leading field. Therefore, considering local students' diverse needs in mastering English Language, the Malaysian Ministry of Education has resorted by implementing the Common European Framework of Reference for Languages (CEFR) aligned curriculum starting from January 2018 in primary schools (Year One and 
Year Two) and secondary schools (Form One and Form Two). It is to ensure Malaysian students to be proficient and suit international standards. Thus, it has further progressed to Year 3 and Form 3 in 2019 and Year 4 and Form 4 in 2020.

CEFR is a framework to cater to the needs of language learners as well as academics and other professions related to assessment, teaching and learning of languages (Uri et al., 2018). It is also a guide developed by the Council of Europe to gauge English Language proficiency and align to international standards. According to Prof Ganakumaran, Malaysian English Language Teaching Association (MELTA) president, "the CEFR standards are determined externally based on language learning research in Europe. These standards allow us to structure what we teach, and assess, to benchmark the progress of our students internationally" (Chin, 2018).

However, the bold decision of its implementation and the use of foreign textbooks in Malaysian schools received mixed views from scholars, parents, teachers, and associations (Sani, 2018). Many claim that foreign textbooks provide rooms to explore the world as the learning style should change with time and global needs. It will surely benefit Malaysian students although it is not an easy transition entering into the new phase (Yeap, 2017).

There are a number of disputes too in the usage of the foreign textbooks such as high cost, credibility of local textbook writers (Aziz et al., 2018) and non-optionists teaching the contents in the book. It is also argued on the suitability of the foreign elements found in the foreign textbooks that might be distant and alien to Malaysian pupils. Apart from being the cause of potential cultural shock, CEFR aligned foreign textbooks lack local context, making it difficult on the whole for students from rural and semi-urban areas. It is also addressed that the content is based on static, British culture where national identity is hard to be seen. ("Let's have our own Textbooks," 2018).

Although there are many researches on foreign textbooks and culture available globally, the students' view on including cultural elements in their English textbooks has not yet been clarified in Malaysian context. So, this study emphases on the perceptions and expectancies of Malaysian students on cultural elements found in foreign textbooks used in their English classrooms, although it is ideally expected that the foreign textbook would be highly welcomed by all parties, including students. It is significant to note that the foreign textbook used by the respondents during their English period in school, Pulse 2 is purchased from the Macmillan Press and its use is compulsory to all secondary schools in Malaysian government schools in teaching English Language.

\section{Cultural Elements in Foreign Textbooks}

The bond between language and culture is inseparable as it is widely immersed in education with the aid of linguists and teachers. Undoubtedly, it is when language is embedded under specific cultural context via the use of textbooks and indirectly learn the culture within it as they learn the target language. According to Xiao (2010), language is also regarded as the medium to convey the inputs and contents for the learners to understand the target culture which is entrenched in the form of illustrations, reading passages, terms used, audios for listening exercises and many more in the textbooks.

Byram (1997) states the advancement of linguistic competence is not able to ensure effective communication, and misunderstandings frequently occur among speakers from distinct cultural environments and experiences. To make it clear, the students who intend to learn English 
INTERNATIONAL JOURNAL OF ACADEMIC RESEARCH IN BUSINESS AND SOCIAL SCIENCES Vol. 10, No. 4, April, 2020, E-ISSN: 2222-6990 @ 2020 HRMARS

Language should not be anticipated to understand and adopt native speakers' cultural norms. On the other hand, the students are urged to have both communicative competence and intercultural competence for effective intercultural communication (Lusi et al., 2018).

Thus, learners discover their culture and other cultures as well using the target language they have learned. The study by Mohammadi (2014) shows that, embedding source culture and target culture in ESL textbooks can assist the students to know the differences between two cultures and make an analysis of cross-cultural understanding.

\section{Problem Statement}

The foreign textbooks used in English Language classrooms claimed to be lack in local contents and focus on the cultures in the English speaking countries which subsides the students' identity as Malaysians. It gives a superior image to the native speakers to learn the language and content.

\section{Aims, Scope of the Study and Research Questions}

The purpose of the study is to explore students' perceptions and expectancies on cultural elements in a secondary school English Language classrooms. Hence, this study aims to answer the questions as follow:

i) What are the students' perceptions on cultural elements in Pulse 2?

ii) What are the students' expectancies on cultural elements that should be depicted in the textbook?

iii) What are the students' perceptions on culture and cultural learning?

\section{Literature Review \\ Language and Culture}

For many decades, the association between language and culture has been studied extensively. Language is commonly used in expressing ideas and communicating information. According to Byram (1992), culture is a structure of meanings embodied in symbols, a system of inherited ideas and expressed under a symbolic shape where people communicate and spread their knowledge pertaining to attitudes to life. Hence, it makes language an important aspect of culture teaching. Language is also denoted as "a human and non-instinctive method of communicating ideas, emotions and desire by means of voluntarily produced symbols." (Sapir, 2002) Languages and cultures are profoundly interconnected and complement each other because both are central parts of our life for communication purpose as evident in many studies.

The study by Nall \& Nall (2009) also explains that language and culture are profoundly interconnected and suggested that languages are hard to be learnt in the absence of attention to the related cultures and languages cannot be learnt without the cultures in which they are spoken. Byram (1988) largely supports the statement in which a language is impossible to be delivered individually without embedding culture, or else, it would lead to a denial of an alleged essential objective of language learning. It is also further supported that language and culture are learned inclusively and are not distinct where it gives support for the progress. (Mitchell \& Myles, 2004) In short, as it is stated above, there is an unbreakable relation between language and culture. Language is greatly evident to be clearly affected and culturally moulded and the main mean in sharing the cultural details. 


\section{Post-Colonialism}

Post-colonialism is a proven theory of the most diverse and contentious fields in language and cultural studies. The Empire Writes Back uses the term 'post-colonial' by referring to "all the culture affected by the imperial process from the moment of colonization to the present day" (Ashcroft, Griffiths \& Tiffin, 1989). Akin to postmodernism, this term summarises a never ending argument of its influences on the colonised countries on the above-stated aspects. (Ashcroft, Griffiths \& Tiffin, 2006) It is also argued that the influence does not cease with the mere fact of political independence and continues to be active in many societies.

As English is a global language and production of literatures and textbooks in English is dominated by the former colonial powers, British colonies. As a result, it is insufficient to use British or other colonial power based texts in school. Moreover, those books influenced by colonial power "can be made to serve colonial interests through educational systems that devaluate native literatures, and by Euro-centric practices which insist on Western texts being markers of superior culture and value" (Loomba, 2015).

The cultural elements and aspects of one's nation simply fades away if it is not embedded via classroom materials such as textbooks with communicative purposes. It also leads to the loss of national identity of a nation. In her book Colonialism/Post colonialism, Ania Loomba (2015) supports that a "nation" is perceived as an "imagined community". While the "nation-state" is a political concept that refers to an administrative apparatus, the "national identity" is "a form of imaginative identification with the symbols and discourses of the nation-state".

As one of the post-colonial countries, Malaysia "needs to also turn its gaze upon itself because when its gaze is turned outward toward the colonisers, it fails to acknowledge its own oppression by enacting the very colonial discourse it opposes" (Jeyakumary et al., 2019).

\section{Cultural Elements}

Cultural elements should be considered as important criteria while dealing with language related areas. Words and expressions conveying particular cultural qualities are indicated as "cultural elements or culture-loaded words" (Gao, 2016). According to Mona Baker (2001), cultural elements are "the source-language word that may express a concept which is totally unknown in the target culture. Having abstract or concrete concept, it may relate to a religious belief, a social custom, or a type of food." As for this paper, "cultural elements" are classified as types and categories of culture.

\section{Types of Culture}

Big " $C$ " culture relates to "the culture that emphases on the products and contribution to a community and its extraordinary people together with politics, economy, history, literature, fine arts, sciences, geography" (Pulverness, 1995 ). Little "c" culture denotes the "way of life", the patterns of everyday life and culture together with the routine elements of life namely food, holidays, lifestyles, customs, values and etcetera.

\section{Categories of Culture}

Source Culture denotes "the own culture of learners", while Target culture relates "to the target language is used as a first language". International culture denotes cultures from countries in which English is the first language and are not a source culture or a target culture; they allude to a multitude 
INTERNATIONAL JOURNAL OF ACADEMIC RESEARCH IN BUSINESS AND SOCIAL SCIENCES Vol. 10, No. 4, April, 2020, E-ISSN: 2222-6990 @ 2020 HRMARS

of cultures which use English as an international language in English or non-English-speaking nations around the world. Culture free related to the textbook contents without referring to any culture or country particularly.

\section{Previous Studies}

Allport (1935) as cited in Pickens (2005) claims that perception is highly associated to attitudes. It is "the process where people interpret and organize sensation to produce a meaningful experience of the world" (Lindsay \& Norman, 1977 as cited in Pickens, 2005). When an individual faces a scenario or stimulus, a perception is acquired. The individual infers the stimulus on the basis of previous experiences into something significant to him or her.

To discuss the topic further, a strong link is found between students' perceptions and expectancies in coherence to cultural elements in the textbook. It is believed that students' perceptions towards it give impact and influence their language and cultural learning process. According to Byram (1997), in his study of attitudes and perceptions towards acquiring cultural knowledge indicated that students' views are very essential as a pre-condition for successful communication. In foreign language teaching is generally assumed that the inclusion of cultural information will have some positive effects on pupils' perceptions and expectancies of the foreign people and culture(s) of which they are learning the language (Sercu, 1988).

The following are the studies and findings related to perceptions and attitudes of students in coherence to the cultural elements in the textbooks. Zhang \& Ma (2004) studied first on their attitude(s) and perception(s) of the cultural elements of college English Language resources in China. The findings showed that the cultural elements used in existing English teaching resources are unsuitable for the students' requirements in China. Many students admit their intents of learning the culture emphasises on target culture, although, more than $50 \%$ of the respondents prefer multicultures together with source and international cultures in teaching materials. Nevertheless, respondents claim most of the textbooks they use focus on target culture.

In Iran, Mansourzadeh et al. (2009) investigated the foreign language culture's role in classrooms. The findings indicated that there is an important resemblance between respondents' attitudes and the cultural frameworks of language they learn. Once the benefits of cultural issues were taken into consideration, students get familiar with the culture of the language, their learning is exceptionally useful whenever considered appropriate and with no favouritism.

Moreover, Xiao (2010) also has examined students' perceptions and attitudes on the cultural contents and culture learning. The researcher collected data through a three-part questionnaire. Researcher found that students had an opinion that target culture is very essential for their English learning and they showed "positive attitudes towards the importance of culture and cultural learning". It is also stated that if the students learn cultural knowledge, it would help their cultural learning better than their current condition.

Hence, these studies have discussed that students are inclined in having interests and positive perceptions of learning target culture in their English Language classrooms. It leads them to be motivated as new inputs are delivered in the class. Nevertheless, there are also some studies which have reported on adverse impacts of the students acquiring the target culture embedded via their foreign textbook. 
As far back as 1993, in the study of English Language classes in Sri Lanka , Canagarjah (1993) as cited in Xiao (2010) indicated that the learners are negatively inclined towards the target language and cultural use. The learners revealed the western biasness in the resources and imbalanced proportion of culture types. The students had anxiety and the dread of having "culturally absorbed" related to the learning. These negative perceptions and attitudes often cause the low motivation, input and interaction and eventually it engraves failure in attaining the language and proficiency (Rahimi \& Hassani, 2012).

To sum up, the above studies show the crucial role of local and foreign textbooks play in ESL classrooms. Although perceptions and attitudes are highly interrelated, this study only explores students' perceptions and expectancies in coherence to cultural elements in Pulse 2.

\section{Methodology \\ Research Design}

Primarily a quantitative study was done as a survey was conducted by distributing an adapted version of bilingual questionnaire from Xiao (2010) to investigate the students' perceptions and expectancies in coherence to cultural elements in the foreign textbooks used in English classrooms. The data obtained via the completed questionnaires were analysed using the Statistical Package for Social Science (SPSS). The succeeding procedures of statistics were used in analysing the data in this research.

\section{Research Subjects}

The questionnaire respondents of this study were 70 Form 2 students from four different classes in SMK Seri Bentong, a suburban national secondary school situated in the Bentong district of Pahang, Malaysia. It was chosen as the research site due to its access to the researcher being a teacher in the school. The respondents' English proficiency and competence were categorised as low intermediate to advanced level in all four learning skills. They were able to write, read, listen and speak to a certain extent. All the students were expected to have completed Pulse 2 ( 9 chapters) in their English Language subject whereby they used it in Form 1 and Form 2. It is significant to note that during their primary school years, English Language was taught with the aid of locally produced textbooks from Year 1 to Year 6 and Pulse 2 was the first imported, foreign textbook to be used by them as the main textbook. All these students responded to the questionnaires.

The sampling techniques used in this paper are purposive and convenience sampling. The research is purposive as the research participants and research sites are selected with intent by the researchers to collect data on the perception and expectancies of students in coherence to cultural elements depicted via Pulse 2. So, in this research, the researcher selected Form 2 students in the school as they are using the textbook, Pulse 2 for the second year consecutively compared to the Form 1 students who were new in using the textbook. Nevertheless, the convenience sampling is also utilised in this research because the researcher-teacher carried out the research in her own school and at her own preferred time. Hence, these steps that the researcher has taken reflect both purposive and convenient sampling. 


\section{Research Instrument}

The questionnaire implemented "a three-pronged approach", which includes a Likert scale responses ( 1 to 5 scales), rank-order questions and open ended responses. The questionnaire was constructed in bilingual (Malay \& English) to ensure the capability to deliver the gist comprehensively to the students.

The bilingual questionnaire adapted the version from Xiao (2010) made up of 2 major parts: (24 items): The first part contained 20 items on the significance of cultural elements where the respondents to rank/order them conferring to the level of their perceptions which is to analyse students perceptions of cultural elements in Pulse 2, their expectancies of cultural types and expectancies of categories should be presented in their English textbook.

The second part consisted of 4 open ended responses about the expectancies in learning culture in regards to the categories of culture. The respondents were deemed to provide relevant reasons too. All the items were adapted from Xiao (2010). The researcher was then required to translate the items into Malay and to check them with the help of two Malay teachers to validate the content and for translation purposes. A pilot study was done prior to the survey.

\section{Data Analysis Plan}

In answering all the research questions, data obtained via the completed questionnaires were analysed using the Statistical Package for Social Science (SPSS). The succeeding procedures of statistics were used in analysing the data in this research. Descriptive statistics were used to calculate the frequencies, average score and standard deviation. To analyse the data, the means were deduced as below:

$$
\begin{aligned}
& 1.00-1.80=\text { Strongly disagree } \\
& 1.81-2.60=\text { Disagree } \\
& 2.61-3.40=\text { Moderately agree } \\
& 3.41-4.20=\text { Agree } \\
& 4.21-5.00=\text { Strongly agree }
\end{aligned}
$$

Moreover, this rank order scores of those items were computed to discover their virtual significance as viewed, hoped and perceived by respondents. Transcription was done after collecting the data of open ended response. Coherently, the data was analysed and concluded.

\section{Findings and Discussion}

A survey was conducted by distributing bilingual questionnaires on the perceptions and expectancies of students in coherence to cultural elements in Pulse 2 and generally in a textbook. It is analysed under following sections and subsections to answer the three research questions.

1.1 Students' perceptions on cultural elements in Pulse 2

1.2 Students' expectancies of cultural elements that should be depicted in a textbook

1.2.1 Students' expectancies of categories of culture that should be depicted in the textbook

1.2.2 Students' expectancies of types of culture and themes that should be depicted in a textbook

1.3 What are the students' perceptions on culture and cultural learning 
INTERNATIONAL JOURNAL OF ACADEMIC RESEARCH IN BUSINESS AND SOCIAL SCIENCES Vol. 10, No. 4, April, 2020, E-ISSN: 2222-6990 @ 2020 HRMARS

\section{Students' Perceptions of cultural elements in Pulse 2}

Table 1.1 shows 5 questions asked in the questionnaire to explore the perceptions of SMK Seri Bentong lower secondary students towards cultural elements depicted in Pulse 2. Mean scores, standard deviations and level of agreement of the students' responses are as below.

Table $1.1 \quad$ Students' Perceptions on cultural elements in Pulse 2

\begin{tabular}{clccc}
\hline Item & \multicolumn{1}{c}{ Students' Perceptions } & $\begin{array}{c}\text { Mean } \\
\text { Scores }\end{array}$ & SD & $\begin{array}{c}\text { Level of } \\
\text { agreement }\end{array}$ \\
\hline 7 & $\begin{array}{l}\text { The culture of English-speaking countries are } \\
\text { often discussed in the book. }\end{array}$ & 4.43 & 0.59 & $\begin{array}{c}\text { Strongly } \\
\text { Agree }\end{array}$ \\
\hline 10 & $\begin{array}{l}\text { There are many different cultures presented in } \\
\text { the book. }\end{array}$ & 3.68 & 1.09 & Agree \\
\hline 6 & $\begin{array}{l}\text { Cultural knowledge contents are included in } \\
\text { most tasks. }\end{array}$ & 3.60 & 1.11 & Agree \\
\hline 9 & $\begin{array}{l}\text { The culture of non-English-speaking countries } \\
\text { is mainly focused upon. }\end{array}$ & 2.53 & 1.9 & Disagree \\
\hline 8 & $\begin{array}{l}\text { Malaysian culture is mainly focused upon in the } \\
\text { book. }\end{array}$ & 1.8 & 0.66 & $\begin{array}{c}\text { Strongly } \\
\text { Disagree }\end{array}$ \\
\hline
\end{tabular}

Based on the data collected from the $6^{\text {th }}$ until $10^{\text {th }}$ items of the questionnaire as shown in Table 1.1, the mean score of students' perceptions were between the ranges of 1.8-4.43 which have level of agreements between strongly disagree to strongly agree. The students strongly agreed on the statement that claimed the culture of English-speaking countries are often discussed in Pulse 2 (Mean=4.43). They also agreed that there are various cultures and cultural knowledge contents are included in the book (Mean=3.68, 3.6). On the contrary, the students disagreed on the statement that stated "The culture of non-English-speaking countries is mainly focused upon" (Mean=2.53). Similarly, they strongly disagreed that Malaysian culture is mainly focused in the book. This shows that the students are well aware of cultural related contents in the textbook and they feel a great absence in source culture and international culture which indicates an imbalance.

According to Cortazzi and Jin (1999) cultures apart from the target culture must receive equal attention in ELT textbooks. Nevertheless, there is no inclusion of Source Culture, students' own culture in the textbook apart from the minimally focused International Culture as in the perception of students. It correlates to the findings by Yuen (2011) and Mahmood, Asghar and Hussain (2012) where there is lack of information about Source Culture in English textbooks.

Washima et al. (1996) stated the relevance in actively promoting materials pertaining to the learners' own culture. According to them the inclusion of Source Culture together with Target Culture in the English textbooks encourages both parties, teachers and students to be aware of the "potential conflicts" and to be critical in responding appropriately to intercultural communication. Chao (2011) also proposes that a balanced distribution of source culture, target culture and international culture materials should be required in the content arrangement of ELT textbooks especially in reading texts. This aids students to deal with a lot of cultural conflicts when there is a process of intercultural communication. Moreover, providing the complementary materials related to target and international culture by the teacher during using this book in class is proposed to support the 
INTERNATIONAL JOURNAL OF ACADEMIC RESEARCH IN BUSINESS AND SOCIAL SCIENCES Vol. 10, No. 4, April, 2020, E-ISSN: 2222-6990 @ 2020 HRMARS

students in gaining intercultural competence (Chao, 2011). According to Chlopek (2008)'s intercultural approach, priority must be given to the students' own culture, followed by the cultures that students have direct contact with. This is because it is possible to embed contents of target culture in locally produced English textbooks but greatly impossible to include source culture in foreign English textbooks that is made relevant to all countries globally.

\section{Students' expectancies of cultural elements to be depicted in a textbook}

Students' Expectancies of categories of culture should be depicted in the textbook

In order to explore the expectancies of students on which category of culture should be highly depicted in their English textbooks used in classrooms, the rank orders of "Target", "International" and "Source" cultures are analysed as it is shown in Table 1.2 and Table 1.3.

Table 1.2 Ranking of students' expectancies of categories of culture that should be depicted in the book

\begin{tabular}{cccc}
\hline Culture & Rank 1 & Rank 2 & Rank 3 \\
\hline Target & 37 & 25 & 18 \\
\hline International & 17 & 13 & 50 \\
\hline Source (Malaysian culture) & 26 & 42 & 12 \\
\hline
\end{tabular}

Referring to the table above, 70 respondents from Form 2 ranked the categories of culture to their own preference as in Rank 1, Rank 2 and Rank 3. For instance, Target Culture which implies the culture of English-speaking countries such as the USA, UK and Australia, is ranked as the first that should be depicted in the textbook by 37 respondents and ranked by 25 respondents as the second. On the other hand, there are 18 respondents who stated that the Target culture is their least preference.

As for the International culture, 17 respondents opt for it as their first preference, 13 respondents as the second and 50 respondents revealed it as their last choice. The results for Source culture (Malaysian culture) shows that 26 respondents ranked it as the first, 42 respondents as the second and 12 respondents as the third. The total value is shown below after each recorded response was converted into value system. For example, Rank $1=3$, Rank $2=2$, and Rank $3=1$. The total value and the rank order is shown in Table 1.3 and Figure 1.1.

Table 1.3 Total value and overall ranking of students' expectancies of categories of culture should be depicted in the book

\begin{tabular}{ccc}
\hline Culture & Total & Rank \\
\hline Target & 253 & $\mathbf{1}$ \\
\hline International & 127 & $\mathbf{3}$ \\
\hline Source (Malaysian culture) & 174 & $\mathbf{2}$ \\
\hline
\end{tabular}


INTERNATIONAL JOURNAL OF ACADEMIC RESEARCH IN BUSINESS AND SOCIAL SCIENCES Vol. 10, No. 4, April, 2020, E-ISSN: 2222-6990 @ 2020 HRMARS

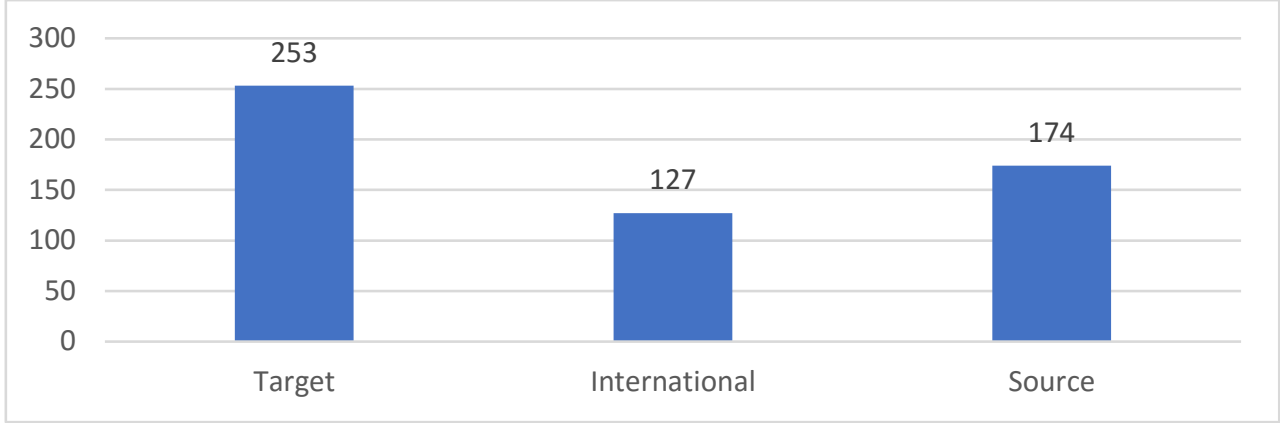

Figure 1.1 Students' expectancies on categories of culture

According to the total value and rank orders shown in Table 1.3 and Figure 1.1, the Form 2 students in SMK Seri Bentong ranked Target culture as the most preferred culture which needs to be embedded in their English textbooks. The Malaysian culture is ranked as the second and international culture as their third choice. The result of this ranking order reveals that, just as it is depicted in the in-use textbook, the students had a firm belief that Target culture is crucial to be learnt than Malaysian and International cultures via textbooks in English classrooms. Table 1.4 shows the percentage of responses given by the students in "yes-or-no" and "open-ended questions" on their interest to learn categories of culture in the past and future.

Table 1.4 Categories of culture and the percentage of interested students

\begin{tabular}{cc}
\hline Categories of Culture & $\begin{array}{c}\text { Percentage of Interested } \\
\text { Students }\end{array}$ \\
\hline Target & $91.3 \%$ \\
\hline International & $91.3 \%$ \\
\hline Source (Malaysian culture) & $88.8 \%$ \\
\hline
\end{tabular}

The above result shows that high percentage of students are interested to learn all the categories of culture in their classrooms. As it was revealed in the earlier section, the students are equally concerned to explore "Target" (English-speaking-countries) and "International" cultures to learn followed by "Source" (Malaysian culture). The following table shows the responses of students from the open ended questions on the reasons they are interested to learn the categories of culture in classrooms. Some of the responses were written in their mother tongue, Malay Language. It was then translated for the research purpose. The reasons are as below: 
INTERNATIONAL JOURNAL OF ACADEMIC RESEARCH IN BUSINESS AND SOCIAL SCIENCES Vol. 10, No. 4, April, 2020, E-ISSN: 2222-6990 @ 2020 HRMARS

Table 1.5 Students' responses on the reasons of their interest in learning culture I will be able to communicate easily with native speakers when I Target further my studies.

I want to compare the culture with my own.

It helps me to learn English Language meaningfully. It broadens my mind to see the world differently

International It helps me to know the customs and values practiced in the country. It will assist me when I visit the countries in future. My favourite celebrities are from those countries.

Source (Malaysian culture)
The cultures in Malaysia are so unique and interesting.

I am a Malaysian and I need to know about Malaysia before anything else.

I have friends from different races and I want to know about them.

\section{Expectancies of types of culture and themes should be depicted in the textbook}

In order to examine the expectancies of students on which types of culture and themes should be depicted in their English textbooks used in classrooms, the rank orders of Big " $\mathrm{C}$ " and little/small " $\mathrm{c}$ " cultures and 11 themes of Chen's (2004) and Lee's (2009) used in textbook analysis are analysed under this section. Students were asked to choose the most preferred 5 themes and rank it from one to five according to their preference as it is shown in Table 1.6.

Table 1.6 Ranking of students' expectancies on themes that should be depicted in the book

\begin{tabular}{ccccccc}
\hline Themes & Rank 1 & Rank 2 & Rank 3 & Rank 4 & $\begin{array}{c}\text { Rank } \\
5\end{array}$ & $\begin{array}{c}\text { Total } \\
\text { Preferences }\end{array}$ \\
\hline History & 6 & 9 & 7 & 6 & 13 & 41 \\
\hline Government \& Politics & 2 & 4 & 6 & 8 & 6 & 26 \\
\hline Literature and Art & 1 & 2 & 0 & 7 & 6 & 16 \\
\hline Music & 3 & 5 & 6 & 11 & 6 & 31 \\
\hline Geography & 0 & 2 & 1 & 2 & 2 & 7 \\
\hline Economy & 1 & 3 & 8 & 3 & 8 & 23 \\
\hline Food & 14 & 13 & 13 & 10 & 5 & 55 \\
\hline Holiday & 8 & 16 & 9 & 6 & 5 & 44 \\
\hline Lifestyle & 18 & 16 & 16 & 14 & 5 & 69 \\
\hline Customs & 20 & 9 & 7 & 8 & 16 & 60 \\
\hline Beliefs \& Values & 7 & 1 & 7 & 5 & 8 & 28 \\
\hline Other & 0 & 0 & 0 & 0 & 0 & 0 \\
\hline Total Respondents & 80 & 80 & 80 & 80 & 80 & \\
\hline
\end{tabular}

Referring to Table 1.6, students' expectancies on themes that should be depicted in their English textbook are shown according to their preferences. All the 80 respondents chose five preferred themes from the list and ranked it accordingly from one to five. The theme with the highest total preference is "lifestyle" with 69 respondents followed by "customs" with 60 respondents and 
INTERNATIONAL JOURNAL OF ACADEMIC RESEARCH IN BUSINESS AND SOCIAL SCIENCES Vol. 10, No. 4, April, 2020, E-ISSN: 2222-6990 @ 2020 HRMARS

"food" by 55 respondents. The total value of top five and bottom five themes are shown below in Table 1.7 after each recorded response was converted into value system. For example, Rank $1=5$, Rank $2=4$, Rank $3=3$, Rank $4=2$ and Rank $5=1$.

Table 1.7 Students' expectancies on top 5 themes should be depicted in the book and its total

\begin{tabular}{cccc}
\multicolumn{4}{c}{ value } \\
\hline Rank & Themes & Types of Culture & Total \\
\hline Rank 1 & Lifestyle & Little / Small “c" & 235 \\
\hline Rank 2 & Customs & Little / Small “c" & 189 \\
\hline Rank 3 & Food & Little / Small “c" & 186 \\
\hline Rank 4 & Holiday & Little / Small “c" & 148 \\
\hline Rank 5 & History & Big “C" & 112 \\
\hline
\end{tabular}

Referring to the data in Table 1.7, top five themes preferred by the students to be included in their English textbook are "Lifestyles" with a total value of 235 followed by "Customs" (189), "Food" (186), "Holiday" (148) and "History" with a total value of 112 respectively. It is also shown that the students are more in favour towards little/small " $c$ " cultures as the first four preferred themes and only the fifth ranked theme is categorised under Big " $\mathrm{C}$ " culture.

There are a few possible reasons on why students are inclined towards small/little " $c$ " culture. This is probably because these small/little " $c$ " cultural topics are rather simple to be learnt, understood, practiced and the centre of attraction of one's culture framework compared to the Big " $C$ " cultures and highly pertinent to communicative competence.

Table 1.8 Students' expectancies on 5 themes that should be least depicted in the book and its

\begin{tabular}{cccc}
\multicolumn{4}{c}{ total value } \\
\hline Rank & Themes & Types of Culture & Total Value \\
\hline Rank 11 & Geography & Big "C" & 17 \\
\hline Rank 10 & Literature \& Art & Big "C" & 33 \\
\hline Rank 9 & Economy & Big "C" & 55 \\
\hline Rank 8 & Government \& Politics & Big “C" & 66 \\
\hline Rank 7 & Belief \& Value & Little / Small "c" & 78
\end{tabular}

It is also important to note the bottom 5 five themes which should be least depicted in the textbook. As it is shown in Table 4.11, the seventh ranked theme is "Belief \& Value" (78), followed by "Government \& Politics" (66), "Economy" (55), "Literature \& Art" (33) and the least preferred theme which holds the last rank is "Geography" (17). Most of these least these least preferred themes are under Big " $C$ " culture.

\section{Perceptions of Culture \& Culture Learning}

Table 1.9 shows 5 questions asked in the questionnaire to explore the perceptions of SMK Seri Bentong lower secondary students towards culture and cultural learning in general. Mean scores, standard deviations and level of agreement of the students' responses are as below. 
INTERNATIONAL JOURNAL OF ACADEMIC RESEARCH IN BUSINESS AND SOCIAL SCIENCES Vol. 10, No. 4, April, 2020, E-ISSN: 2222-6990 @ 2020 HRMARS

Table 1.9 Students' Perceptions on culture and cultural learning

\begin{tabular}{clccc}
\hline Item & \multicolumn{1}{c}{ Students' Perceptions } & $\begin{array}{c}\text { Mean } \\
\text { Scores }\end{array}$ & SD & $\begin{array}{c}\text { Level of } \\
\text { agreement }\end{array}$ \\
\hline $\mathbf{3}$ & $\begin{array}{l}\text { It is very important for me to know Malaysian } \\
\text { culture. }\end{array}$ & 4.30 & 0.64 & $\begin{array}{c}\text { Strongly } \\
\text { Agree }\end{array}$ \\
\hline $\mathbf{2}$ & $\begin{array}{l}\text { It is very important for me to know about } \\
\text { English-speaking countries. }\end{array}$ & 4.2 & 0.40 & Agree \\
\hline $\mathbf{5}$ & $\begin{array}{l}\text { It is very important for me to know about daily } \\
\text { living and culture patterns such as food, } \\
\text { holidays, lifestyles and customs. }\end{array}$ & 1.07 & Agree \\
\hline $\mathbf{1}$ & $\begin{array}{l}\text { I want to learn cultural elements and } \\
\text { language. }\end{array}$ & 4.0 & 0.78 & Agree \\
\hline $\mathbf{4}$ & $\begin{array}{l}\text { It is very important for me to know the culture } \\
\text { of non-English-speaking countries. }\end{array}$ & 3.28 & 1.03 & Moderately \\
\end{tabular}

As it is shown in Table 1.9, items 1-5 indicate the students' perceptions on culture and cultural learning which are positively inclined in general. All the above responses from 5 items were strongly agreed, agreed and moderately agreed with mean scores ranging from 3.28-4.3. The students view culture and its learning, in terms of Target, Source and International as well as Big " $C$ ' and little " $c$ " cultures, vital as they showed considerably high awareness and responsiveness towards it. Nevertheless, the students graded the cultural categories differently in reference to the level of importance when they were required to respond to the items which show their varied level of interests and preferences.

In order to explore more on students' perceptions on cultural learning, the most useful method used by teachers to teach culture and several factors that may cause the students disregard cultural learning in English classrooms were analysed. As it was done in previous sections, the students were required to choose three options from the list that they strongly agree with and rank it in order. Their responses are presented in Table 1.10.

Table 1.10 Students perceptions on the most useful methods for cultural learning

\begin{tabular}{|c|c|c|c|}
\hline ITEM & LEARNING METHODS & $\begin{array}{l}\text { NO. OF } \\
\text { RESPONDENTS }\end{array}$ & PERCENTAGE \\
\hline M6 & WATCHING MOVIES & 27 & $33.8 \%$ \\
\hline M4 & $\begin{array}{l}\text { TEACHERS INTRODUCING CULTURE BY TALKING } \\
\text { ABOUT CELEBRATIONS OR FESTIVALS RELATED TO } \\
\text { CULTURE. }\end{array}$ & 21 & $26.2 \%$ \\
\hline M1 & $\begin{array}{l}\text { TEACHERS GIVING CULTURAL INFORMATION RELATED } \\
\text { TO THE TOPICS }\end{array}$ & 12 & $15 \%$ \\
\hline M2 & $\begin{array}{l}\text { TEACHERS GIVING OPPORTUNITIES TO DISCUSS THE } \\
\text { SIMILARITIES AND DIFFERENCES OF CULTURE IN CLASS }\end{array}$ & 10 & $12.5 \%$ \\
\hline M5 & ROLE PLAYS & 4 & $5 \%$ \\
\hline M3 & $\begin{array}{l}\text { STUDENTS FINDING MORE CULTURAL } \\
\text { INFORMATION FROM NEWSPAPERS, MAGAZINES } \\
\text { AND BOOKS AFTER CLASS. }\end{array}$ & 4 & $5 \%$ \\
\hline
\end{tabular}


INTERNATIONAL JOURNAL OF ACADEMIC RESEARCH IN BUSINESS AND SOCIAL SCIENCES Vol. 10, No. 4, April, 2020, E-ISSN: 2222-6990 @ 2020 HRMARS

Table 1.10 shows that the students perceived that the most useful teaching method to learn culture in their classrooms were "watching movies" related to cultural contents and followed by "teachers introducing culture by talking about celebrations or festivals related to culture" in their learning sessions. The above results revealed that the students need fun learning method and teachers' assistance, "teacher-centred approach" to learn culture rather than working voluntarily and individually which is a student-centred approach to ignite their interest in this field of knowledge.

On the other hand, it is also important to analyse the hindrance factors that cause the students disregard cultural learning as it shows a great association with the best methods to learn it. Table 1.11 presents the students' perceptions on the hindrance factors for them to learn culture via choosing and ranking the options from the list provided in the questionnaire.

\begin{tabular}{|c|c|c|c|}
\hline Table 1.11 & \multicolumn{3}{|c|}{ Students perceptions on hindrance of learning culture } \\
\hline Item & Hindrance Factors & $\begin{array}{l}\text { No. of } \\
\text { respondents }\end{array}$ & Percentage \\
\hline F3 & Textbooks lack cultural elements & 30 & $37.5 \%$ \\
\hline F4 & Boring and uninteresting way of teaching & 19 & $23.8 \%$ \\
\hline F5 & $\begin{array}{l}\text { I have to pass the exam. There was no } \\
\text { time to learn about cultures. }\end{array}$ & 12 & $15 \%$ \\
\hline F1 & Teachers don't teach cultural information & 10 & $12.5 \%$ \\
\hline $\mathbf{F 2}$ & $\begin{array}{l}\text { Cultural learning is not as important as } \\
\text { learning grammar. }\end{array}$ & 7 & $8.8 \%$ \\
\hline
\end{tabular}

Referring to Table 1.11, the students stated that the biggest factor that makes them disregard culture and cultural learning is "the textbooks that lack cultural elements". They believe that the contents in the textbook are not sufficient to cater them with cultural knowledge and to explore various cultures. Apart from the contents in the textbook, the students also ranked "boring and uninteresting way of teaching" as the second biggest factor. It signifies that the students hope for other exciting ways to learn culture rather than mere chalk-and-talk or traditional approaches and teachers may need to 'amalgamate' with the ways students prefer.

\section{Conclusion}

In pertinence to the students' perception on the textbook and the cultural elements in it, the results showed that they perceive the dominance in inclusion of the culture of English speaking countries (Target) in the book and expect for contents that encompass on Source and International Culture. Although they agree that many different cultures are presented in the book but they are also well aware that Malaysian culture (Source Culture) is not given emphasis in the textbook they use in their English Language classrooms. Most of them were highly interested to learn all cultures in a balanced proportion in English classrooms. Despite of their interest, they perceive that Target culture is the most important culture alongside Source and International for them to learn and explore. Textbook policy is deemed to achieve the balance. 
INTERNATIONAL JOURNAL OF ACADEMIC RESEARCH IN BUSINESS AND SOCIAL SCIENCES

Vol. 10, No. 4, April, 2020, E-ISSN: 2222-6990 @ 2020 HRMARS

\section{Implications}

This study on Malaysian secondary school students' perceptions and expectancies on foreign textbooks and its cultural elements will give awareness about the extensively used cultural elements in foreign textbooks and in English Language classroom materials. It will also increase the cultural consciousness of the students, enhance their cultural learning and intercultural communication competence. Textbook policies may provide a framework of balanced cultural elements to be included in textbooks as they can contribute to improve quality an equity in education and significantly influences national development and social cohesion in the country. Thus, a real difference is made.

\section{Recommendations}

Based on the analysis of the findings of the present study, the researchers propose a few recommendations. First and foremost, the findings of the study disclose that the students perceive that Pulse 2 is heavily loaded with cultural elements related to Target culture and has minimally embedded International culture, whereas Malaysian source culture is not included. Subsequently, the textbook authors and curricula planners are proposed to create a similar percentage or a balance between the target culture, Malaysian Source culture and International cultures in ESL textbooks as it teaches cultural tolerance and gives awareness to the young generation to understand the people from multitude of cultural backgrounds. Hence, it bridges the gap among cultures globally. In addition, it is also proposed that that the textbooks used in English Language classrooms should include wide range of Big " $\mathrm{C}$ " cultural topics such as "Economy", "Education", "Architecture" and "Music" that matches students' preferences.

Apart from the textbook, it is suggested that the Teacher's Books should be catered with related cultural information extensively and some guidance and links on how to teach culture, not only via reading but also through other language skills with other in-class activities. In this light, both teacher and student parties have additional exposure to have meaningful teaching learning session. In future, similar researches on foreign textbooks can be conducted by analysing other textbooks including local and commercial textbooks can be analysed too to do comparative studies.

\section{Acknowledgement}

I would like to heartily thank my supervisor, Dr Azlina Abdul Aziz (Faculty of Education, Universiti Kebangsaan Malaysia, Bangi, Selangor) for her wonderful guidance, assistance and continuous support in guiding me to complete the article. I also thank my parents, family members and friends who have been the pillars of support in strengthening me to complete this journey of research. They made this possible. The authors also acknowledge Universiti Kebangsaan Malaysia for creating an opportunity to conduct the research.

\section{References}

Ashcroft, B., Griffiths, G., \& Tiffin, H. (2006). The Post-colonial Studies Reader Second Edition. London: Routledge.

Ashcroft, B., Griffiths, G., \& Tiffin, H. (1989). The Empire Writes Back. DOI: 10.4324/9780203426081 
INTERNATIONAL JOURNAL OF ACADEMIC RESEARCH IN BUSINESS AND SOCIAL SCIENCES Vol. 10, No. 4, April, 2020, E-ISSN: 2222-6990 @ 2020 HRMARS

Aziz, A. H. A. A., Ab Rashid, R., \& Zainudin, W. Z. W. (2018). The enactment of the Malaysian common European framework of reference (CEFR): National master trainer's reflection. Indonesian Journal of Applied Linguistics, 8(2), 409-417.

Baker, M. (1992). In Other Words. London, UK: Routledge.

Baker, M. (2001). Routledge Encyclopedia of Translation Studies. London, UK: Routledge.

Byram, M. (1988). Foreign language education and cultural studies. Language, culture and curriculum, 1(1), 15-31.

Byram, M. (1997). Cultural Studies and foreign language teaching. London, UK: Routledge.

Canagarjah, A. S. (1993). Critical ethnography of a Sri Lankan classroom: Ambiguities in opposition to reproduction through ESOL. TESOL Quarterly, 27(4), 601-626.

Chao, T. C. (2011). The hidden curriculum of cultural content in internationally published ELT textbooks: A closer look at new American inside out. Journal of Asia TEFL, 8(2), 189-210.

Chen, B. B. (2004). A survey on cultural learning and its variables analysis. Xi'an: Journal of Xi'an International Studies University, 12(3), 21-24.

Chin, C. (2018). Building on a Benchmark. The Star. Retrieved from https://www.thestar.com.my/news/education/2018/02/04/building-on-a-benchmark/

Chlopek, Z. (2008). The Intercultural Approach to EFL Teaching and Learning. English Teaching Forum, 46(4), 10.

Cortazzi, M., \& Jin, L. X. (1999). Cultural mirrors: materials and methods in the EFL classroom. In E. Hinkel, (ed.), Culture in Second Language Teaching and Learning (pp. 196-219). Cambridge, UK: Cambridge University Press.

Gao, J. (2016). The translation of cultural elements in Wei Cheng from Chinese into English/Gao Jiao (Doctoral dissertation). Retrieved from http://studentsrepo.um.edu.my/6666/

Lee, K-Y. (2009). Treating culture: What 11 High School EFL Conversation Textbooks in South Korea. English Teaching: Practice and Critique, 8(1), 76-96.

Let's have our own Textbooks (2018), The Star. Retrieved from https://www.thestar.com.my/news/education/2018/02/04/lets-have-our-own-textbooks/

Loomba, A. (2015). Colonialism-postcolonialism. New York, NY: Routledge.

Lusi, M., Joko, N., \& Slamet, S. (2018). Cultural Content: An Analysis of EFL Textbook in Indonesia. International Journal of Scientific and Research Publications (IJSRP), 8(11).

Mahmood, M. A., Asghar, Z. M., \& Hussain, Z. (2012). Cultural representation in ESL textbooks in Pakistan: A case study of "Step Ahead 1". Journal of Education and Practice, 3(9), 35-42.

Mansourzadeh, N., Panahanda, E., Hosseini, Y., \& Sanaeezadeh, A. (2009). Culture: Its Manifestations in the Classrooms. Journal of Elementary Education, 24(2), 65-80.

Mitchelle, R., \& Myle, F. (2004). Second Language Learning Theories. London, UK: Hodder Arnold.

Mohammadi, M., \& Abdi, H. (2014). Textbook Evaluation: A Case Study. Procedia - Social and Behavioral Sciences, 98, 1148-1155. doi:10.1016/j.sbspro.2014.03.528

Nall, S. P., \& Nall, T. M. (2009). Language and Culture: Their Relationships and Linguistic Impact. Retrieved from http://ir.lib.au.edu.tw/dspace/bitstream/987654321/2619/1/CH10conf.200\%209_su03_01.pdf

Narayanasamy, J., Aziz, A. A., Mohamad, M., \& Hameed, H. A. (2019). Student-Teachers' experiences in developing oral history texts. 3L: Language, Linguistics, Literature $^{\circledR}$, 25(3), 79-89.

Pennycook, A. (2018). Posthumanist applied linguistics. London, UK: Routledge. 
INTERNATIONAL JOURNAL OF ACADEMIC RESEARCH IN BUSINESS AND SOCIAL SCIENCES

Vol. 10, No. 4, April, 2020, E-ISSN: 2222-6990 @ 2020 HRMARS

Pickens, J. (2005). Attitudes and perceptions. Organizational Behavior in Health Care, 4(7), 43-76.

Pulverness, A. (1995). Cultural Studies, British Studies and EFL. Modern English Teacher, 4(2), 7-11.

Rahimi, M., \& Hassani, M. (2012). Attitude towards EFL textbooks as a predictor of attitude towards learning English as a foreign language. Procedia-Social and Behavioral Sciences, 31, 66-72.

Sani, R. (2018). Building capacity to increase English proficiency. News Straits Times. Retrieved from https://www.nst.com.my/education/2018/02/332968/building-capacity-increase-englishproficiency

Sapir, E. (2002). Language: An Introduction to the Study of Speech. Beijing: Foreign Language Teaching and Research Press.

Sercu, L. (2000). Acquiring intercultural communicative competence from textbooks. The case of Flemish adolescents learning German. Leuven, Belgium: Leuven Uruversity Press.

Uri, N. F. M., \& Aziz, M. S. A. (2018). Implementation of CEFR in Malaysia: Teachers' awareness and the Challenges. 3L: Language, Linguistics, Literature ${ }^{\circledR}, 24(3), 168-183$.

Washima, C. D., Harshita, A. H., \& Naysmith, J. (1996). English and Islam in Malaysia: Resolving the Tension. World Englishes, 15(2), 6.

Xiao, J. (2010). Cultural contents of an in-use EFL textbook and English major students' attitudes and perceptions towards culture learning at Jiangxi University of Science and Technology, China (Doctoral dissertation). Prince of Songkla University, Thailand.

Yeap, A. (2017). Better books mean better Learning. The Star. Retrieved from https://www.thestar.com.my/metro/metro-news/2017/12/09/better-books-mean-betterlearning-teachers-in-ipoh-are-all-for-the-use-of-imported-textbooks-that-wi

Ka-Ming, Y. (2011). The Representation of foreign culture in English textbooks. ELT Journal, 65(4), 458-466.

Zhang, B., \& Ma, L. (2004). A Survey on the Cultural Content of College English Teaching Materials (J). Foreign Language World, 2004(4), 60-66. 